\title{
Adenosine Receptors Modulate the Exogenous Ketogenic Supplement-Evoked Alleviating Effect on Lipopolysaccharide-Generated Increase in Absence Epileptic Activity in WAG/Rij Rats
}

\author{
Brigitta Brunner ${ }^{1,2} \mathbb{( D}$, Csilla Ari ${ }^{3,4, * \mathbb{D}}$, Dominic P. D'Agostino ${ }^{3,5,6}$ and Zsolt Kovács ${ }^{2}(\mathbb{D}$ \\ 1 Faculty of Sciences, Institute of Biology, University of Pécs, Ifjúság Str. 6, 7624 Pécs, Hungary; \\ brunnerb28@gmail.com \\ 2 Savaria University Centre, Department of Biology, ELTE Eötvös Loránd University, Károlyi Gáspár tér 4, \\ 9700 Szombathely, Hungary; zskovacsneuro@gmail.com \\ 3 Ketone Technologies LLC, Tampa, FL 33612, USA; ddagosti@usf.edu \\ 4 Behavioral Neuroscience Research Laboratory, Department of Psychology, University of South Florida, \\ Tampa, FL 33620, USA \\ 5 Laboratory of Metabolic Medicine, Department of Molecular Pharmacology and Physiology, Morsani College \\ of Medicine, University of South Florida, Tampa, FL 33612, USA \\ 6 Institute for Human and Machine Cognition, Ocala, FL 34471, USA \\ * Correspondence: csari2000@yahoo.com; Tel.: +1-(813)-2409925
}

Citation: Brunner, B.; Ari, C.; D'Agostino, D.P.; Kovács, Z. Adenosine Receptors Modulate the Exogenous Ketogenic SupplementEvoked Alleviating Effect on Lipopolysaccharide-Generated Increase in Absence Epileptic Activity in WAG/Rij Rats. Nutrients 2021, 13, 4082. https://doi.org/10.3390/ nu13114082

Academic Editors: Keisuke Hagihara and Lindsay Brown

Received: 27 September 2021 Accepted: 11 November 2021 Published: 15 November 2021

Publisher's Note: MDPI stays neutral with regard to jurisdictional claims in published maps and institutional affiliations.

Copyright: () 2021 by the authors. Licensee MDPI, Basel, Switzerland. This article is an open access article distributed under the terms and conditions of the Creative Commons Attribution (CC BY) license (https:// creativecommons.org/licenses/by/ $4.0 /)$.

\begin{abstract}
It has been previously demonstrated that KEKS food containing exogenous ketogenic supplement ketone salt (KS) and ketone ester (KE) decreased the lipopolysaccharide (LPS)-generated increase in SWD (spike-wave discharge) number in Wistar Albino Glaxo/Rijswijk (WAG/Rij) rats, likely through ketosis. KEKS-supplemented food-generated ketosis may increase adenosine levels, and may thus modulate both neuroinflammatory processes and epileptic activity through adenosine receptors (such as A1Rs and A2ARs). To determine whether these adenosine receptors are able to modify the KEKS food-generated alleviating effect on LPS-evoked increases in SWD number, an antagonist of A1R DPCPX (1,3-dipropyl-8-cyclopentylxanthine; $0.2 \mathrm{mg} / \mathrm{kg}$ ) with LPS (50 $\mu \mathrm{g} / \mathrm{kg})$ and an antagonist of A2AR SCH58261 (7-(2-phenylethyl)-5-amino-2-(2-furyl)-pyrazolo-[4,3-e]-1,2,4triazolo[1,5-c]pyrimidine; $0.5 \mathrm{mg} / \mathrm{kg}$ ) with LPS were co-injected intraperitoneally (i.p.) on the ninth day of KEKS food administration, and their influence not only on the SWD number, but also on blood glucose, R-beta-hydroxybutyrate (R- $\beta \mathrm{HB}$ ) levels, and body weight were measured. We showed that inhibition of A1Rs abolished the alleviating effect of KEKS food on LPS-generated increases in the SWD number, whereas blocking A2ARs did not significantly modify the KEKS food-generated beneficial effect. Our results suggest that the neuromodulatory benefits of KEKS-supplemented food on absence epileptic activity are mediated primarily through A1R, not A2AR.
\end{abstract}

Keywords: ketogenic supplements; ketosis; adenosine receptors; LPS; absence epilepsy; WAG/Rij rats

\section{Introduction}

Digestion of administered exogenous ketogenic supplements (EKSs), such as ketone salts and ketone esters (KSs and KEs, respectively) can liberate ketone bodies, such as beta-hydroxybutyrate $(\beta \mathrm{HB})$ and acetoacetate $(\mathrm{AcAc})$ [1]. These molecules can transport to the bloodstream and are able to evoke an increase in ketone body levels (therapeutic ketosis) without dietary restriction, such as a ketogenic diet [2,3]. After that, ketone bodies may be transported to different cells (such as neurons and glia) through monocarboxylate transporters and can be readily used as an energy source in the mitochondria [4,5]. Indeed, adaptation of the brain metabolism to ketone bodies as a main source of fuel was demonstrated [6,7]. It is widely accepted that ketone bodies (e.g., $\beta \mathrm{HB})$, are not only a potential 
energy source for different tissues of the body, but also signaling molecules for the central nervous system's processes [4,5]. Moreover, administration of EKSs can significantly increase and sustain the blood level of ketone bodies, which is a safe and well-tolerated method to evoke nutritional ketosis [2,3]. Thus, EKSs may be able to alleviate symptoms of different central nervous system diseases by elevating ketones independent of changing dietary macronutrient composition [2,3,8]. Indeed, EKSs showed therapeutic potential, for example, in the treatment of anxiety [2,9], different types of seizure disorders [10,11], amyotrophic lateral sclerosis [12,13], as well as Alzheimer's disease and Parkinson's disease $[14,15]$. However, despite the potential beneficial effects of EKS administration in the treatment of central nervous system disorders, their mechanism(s) of action are largely unknown.

It was suggested that EKS-evoked ketosis can attenuate inflammatory processes [16]. Moreover, inflammation may have a role in the pathomechanism of absence epilepsy [17,18]. Consequently, EKSs may be able to generate alleviating influences on absence epileptic activity through modulation of inflammatory processes. Indeed, administration of EKSs decreased not only spontaneous absence epileptic seizures [11], but also lipopolysaccharide (LPS)-generated increases in the number of spike-wave discharges (SWDs) [19] in a rat model of human absence epilepsy (Wistar Albino Glaxo/Rijswijk rat: WAG/Rij rat). In this model, the focal onset of seizures in the cortex (cortical focus) was triggered and the genesis caused rapid propagation in SWDs in electroencephalograms (EEG) $[20,21]$. It was also demonstrated that inflammatory processes can precipitate and aggravate epileptic seizures [22], for example in WAG/Rij rats $[17,18,23]$ likely via Toll-like receptor 4 (TLR4)/interleukin-1 $\beta$ (IL-1 $\beta$ )/cyclooxygenase-2 (COX-2)/prostaglandin $\mathrm{E}_{2}\left(\mathrm{PGE}_{2}\right)$ system [22-25], leading to increased cortical excitability and thereby enhancing absence epileptic activity in WAG/Rij rats $[17,23]$. Moreover, it has also been suggested that adenosine has a role in the modulation of neuroinflammatory processes via its receptors, such as inhibitory (A1) and excitatory (A2A) adenosine receptors (A1Rs and A2ARs, respectively) [26,27], which receptors (and the adenosinergic system) are implicated in the pathomechanism of absence epilepsy [28,29], at least in WAG/Rij rats. Since EKSs-evoked ketosis may increase the adenosine level [30], we hypothesized that A1Rs and/or A2ARs may modulate the EKSs-evoked beneficial influences on LPS-generated aggravation in absence epileptic seizures (SWD number). Thus, we investigated the effect of an A1R antagonist (DPCPX: 1,3-dipropyl-8-cyclopentylxanthine) and an A2AR antagonist (SCH58261: 7-(2-phenylethyl)-5-amino-2-(2-furyl)-pyrazolo-[4,3-e]-1,2,4-triazolo[1,5-c]pyrimidine) on generated alleviating influence of ketone-supplemented food (KEKS food) on LPS-evoked increase in SWD number in WAG/Rij rats.

\section{Materials and Methods}

\subsection{Animals}

Animal treatments and surgeries were carried out based on the guidelines of the Hungarian Act of Animal Care and Experimentation (1998, XXVIII, Section 243), European Communities Council Directive 24 November 1986 (86/609/EEC) and EU Directive 2010/63/EU (license number VA/ÉBNTF02/85-8/2016; National Scientific Ethical Committee on Animal Experimentation, Hungary). Pain and suffering, as well as the number of experimental animals were minimized.

WAG/Rij male rats (10 months old, 304-328 g; breeding colony of rats at ELTE Savaria University Centre, Szombathely, Hungary) were used. Animals were housed in groups (containing 3-4 rats per group) under standard laboratory conditions (we provided a 12:12 h light-dark cycle; light was on: 08.00 a.m.-08.00 p.m.; free access to water and food; air-conditioned rooms: $22 \pm 2{ }^{\circ} \mathrm{C}$ ).

\subsection{Electrode Implantation}

Electrode implantation for EEG recording was carried out under isoflurane anesthesia (Isoflurane was $2.0-2.5 \%$ in an Isoflurane-air mixture) [31]. Stainless steel screw electrodes 
were implanted epidurally above the frontal cortex and parietal cortex (based on stereotaxic coordinates: AP $2.0 \mathrm{~mm}$, L $2.1 \mathrm{~mm}$ and AP $-6.5 \mathrm{~mm}$, L $2.1 \mathrm{~mm}$, respectively) [32]. Ground screw electrodes and reference electrodes were implanted above the cerebellar cortex [33]. Electrodes were soldered to a ten-pin socket. Finally, dentacrylate cement (Ivoclar, Liechtenstein) was used to fix the electrodes to the skull. To alleviate post-operative pain, lidocaine ointment (5\%; EGIS, Hungary) was used.

\subsection{EEG Recording and Evaluation}

Rats $(n=33)$ were allowed to recover from surgery for 2 weeks (recovery period) before the recording of EEG. EEG recording was carried out by the Bioamp4 differential amplifier (Supertech Ltd., Pécs, Hungary) and the CED $1401 \mathrm{mkII}$ device (Cambridge Electronic Design Ltd., UK, Cambridge) between 1.30 p.m. and 4.00 p.m. (sampling rate: $500 \mathrm{~Hz}$; bandwidth of the EEG recording: $0.3 \mathrm{~Hz}$ to $150 \mathrm{~Hz}$ ) [34].

As handling may evoke stress, which can induce changes in both the behavior of rats and, thereby, the SWD number for about 20-25 $\mathrm{min}[20,23,34]$, we evaluated the SWD number between 30 and 150 min of recording periods similar to previous studies [11,19]. However, it was also observed $[23,35]$ that behavioral changes and its effect on SWD number disappeared within 25-30 min after treatments. One-hour sections of EEG recordings were evaluated separately [23]. SWDs were separated manually from the EEG based on their main features (SWDs consist a train of asymmetric spikes and slow waves; discharge frequency within SWDs: 7-11 Hz; averaged SWD duration: 1-30 s) [20].

\subsection{Administration of Exogenous Ketogenic Supplements and Different Drugs}

It has been previously demonstrated that ad libitum feeding of rats by ketone- supplemented food with a paste-like consistency (KEKS food: 10\% KE/R,S-1,3-butanediolacetoacetate diester and $10 \% \mathrm{KS} / \mathrm{Na}^{+}$and $\mathrm{Ca}^{2+}$-ketone salt, $\%$ by weight, were mixed with powdered standard rodent chow, 1\% saccharine and water) increased blood ketone body level and decreased the number of spontaneously developed SWDs between 6-9 days of administration without side effects in WAG/Rij rats [19]. It was also demonstrated that KEKS food also decreased the LPS-generated increase in SWD number on the ninth day of KEKS food administration in WAG/Rij rats [19]. Consequently, we fed the animals with KEKS food for nine days. Moreover, based on our previous results $[11,23,31,34]$ on WAG/Rij rats, we intraperitoneally (i.p.) administered the effective and well-tolerated dose of LPS (50 $\mathrm{\mu g} / \mathrm{kg}$; Sigma-Aldrich, Inc., Hungary) alone; LPS with both a non-proepileptic dose of an A1R antagonist DPCPX (0.2 mg/kg; Sigma-Aldrich, Inc., Hungary) (DPCPX + LPS) and non-antiepileptic dose of an A2AR antagonist SCH58261 (0.5 mg/kg; Sigma-Aldrich, Inc., Hungary) (SCH58261 + LPS); and KEKS food with LPS (KEKS food + LPS), with DPCPX and LPS (KEKS food + DPCPX + LPS) and SCH58261 and LPS (KEKS food + SCH58261 + LPS). As $1-30 \%$ dimethyl sulfoxide (DMSO) solution did not change absence epileptic activity in WAG/Rij rats [36], both DPCPX and SCH58261 were dissolved in 10\% DMSO (Sigma-Aldrich Inc., Hungary) solution, whereas LPS was administered in saline [23,31].

\subsection{Treatments and Animal Groups}

After the recovery period, rats were assigned into six groups (Figure 1). For the adaptation of animals to the experimental procedures, rats were handled and EEG recordings were carried out every day for 5 days. During these 5 days (adaptation period), animals were fed by powdered standard rodent chow, which was mixed with water and 1\% saccharine (paste-like standard rodent chow without KEKS) for adaptation of animals not only to EEG recordings, but also to paste-like food. Then, in order to determine the averaged control SWD number, all of the rats were further fed with paste-like standard rodent chow (without KEKS) on three consecutive days. Moreover, all rats were i.p. injected by saline (first injection; $0.3 \mathrm{~mL} / 100 \mathrm{~g}$ body weight) and it was followed by the same saline injection (30 min later; second injection; $0.3 \mathrm{~mL} / 100 \mathrm{~g}$ body weight) on the three-day control period, and the EEG recording was carried out (three-day control period). 


\section{GROUP 1}

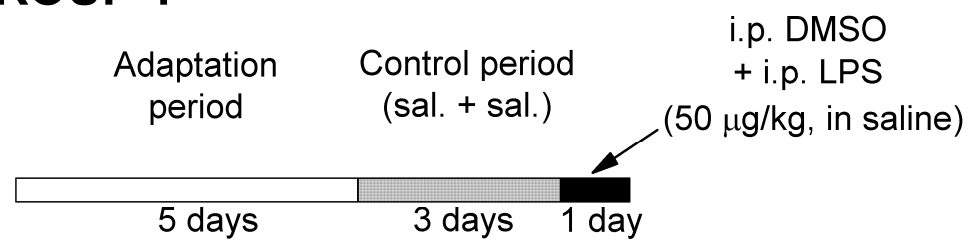

\section{GROUP 2}

i.p. DPCPX

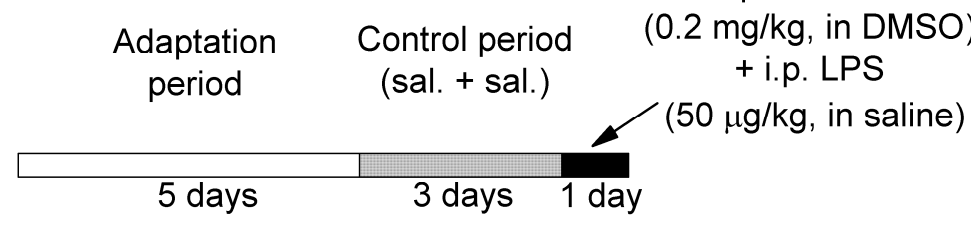

\section{GROUP 3}

i.p. $\mathrm{SCH} 58261$

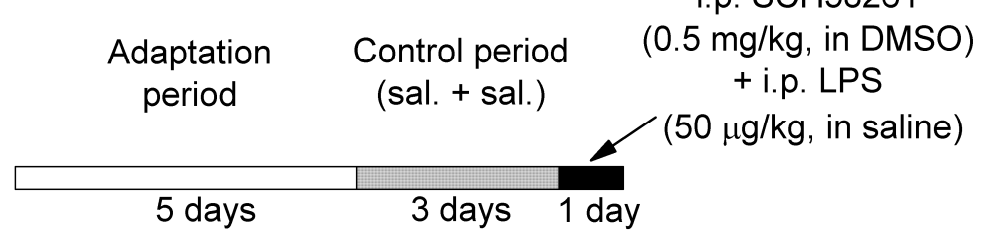

\section{GROUP 4}

\section{$\begin{array}{ccc}\begin{array}{c}\text { Adaptation } \\ \text { period }\end{array} & \begin{array}{c}\text { Control period } \\ \text { (sal. + sal.) }\end{array} & \text { KEKS days } \\ \text { (sal. + sal. }\end{array}$}

\begin{tabular}{|ccc}
\multicolumn{1}{c}{$($ sal. + sal. $)$} & $\begin{array}{c}\text { (sal. }+ \text { sal. } \\
\text { between } 1 \text { st and } 8 \text { th days })\end{array}$ \\
\hline 5 days & 3 days & 9 days
\end{tabular}

On the 9th KEKS day:

i.p. DMSO

+ i.p. LPS

$(50 \mu \mathrm{g} / \mathrm{kg}$, in saline)

\section{GROUP 5}

On the 9th KEKS day:

$$
\text { i.p. DPCPX }
$$

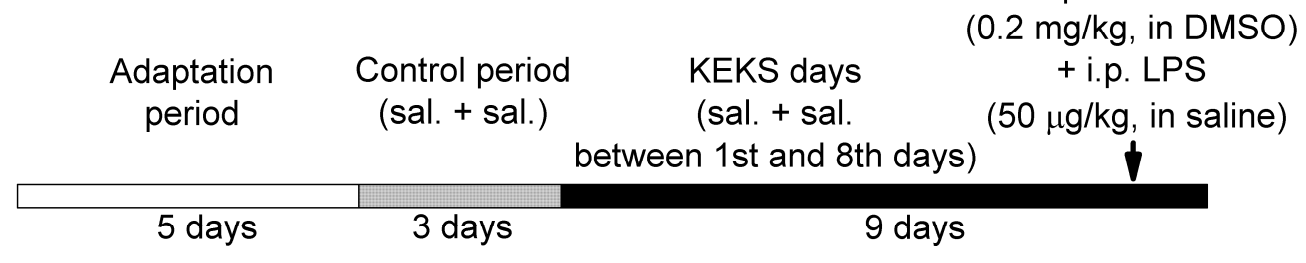

\section{GROUP 6}

On the 9th KEKS day:

i.p. SCH58261

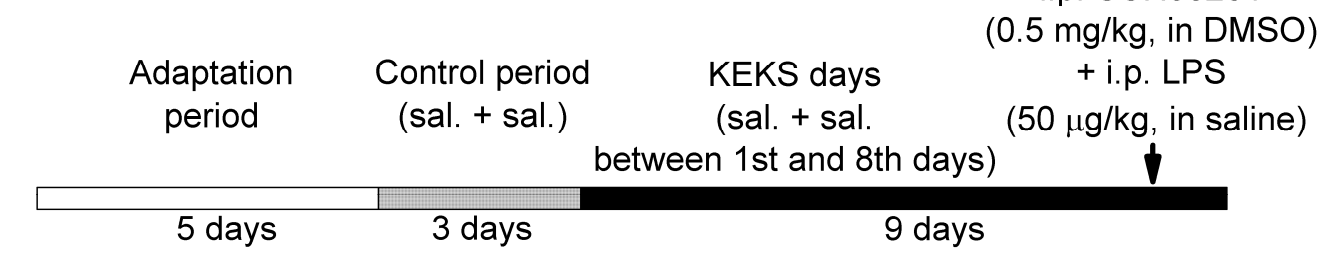

Figure 1. Experimental design. Abbreviations: DMSO, dimethyl sulfoxide; DPCPX, 1,3-dipropyl-8-cyclopentylxanthine; i.p., intraperitoneal; KEKS days, days KEKS food (10\% ketone ester/KE, 10\% ketone salt/KS and 1\% saccharin in paste-like standard rodent chow) administration; LPS, lipopolysaccharide; sal. + sal.: i.p. $0.3 \mathrm{~mL}$ saline/100 g body weight (first injection) + $0.3 \mathrm{~mL}$ saline/100 g body weight (second injection; $30 \mathrm{~min}$ later); SCH582361, 7-(2-phenylethyl)-5-amino-2-(2furyl)-pyrazolo-[4,3-e]-1,2,4-triazolo[1,5-c]pyrimidine.

After three-day control periods, animals in groups 1-3 received two i.p. injections (first injections were followed by second injections $30 \mathrm{~min}$ later) on the fourth day of 
the experiments, and EEGs were recorded (Figure 1). In relation to group $1(n=5), 10 \%$ DMSO solution $(0.3 \mathrm{~mL} / 100 \mathrm{~g}$ body weight; first injection) and LPS $(50 \mu \mathrm{g} / \mathrm{kg})$ in $0.3 \mathrm{~mL}$ saline $/ 100 \mathrm{~g}$ body weight (second injection) were injected. A combined injection of DPCPX (first injection; i.p. $0.2 \mathrm{mg} / \mathrm{kg}$ in $0.3 \mathrm{~mL} \mathrm{10 \%} \mathrm{DMSO} \mathrm{solution/100} \mathrm{g} \mathrm{body} \mathrm{weight)} \mathrm{with} \mathrm{LPS}$ (second injection; $50 \mu \mathrm{g} / \mathrm{kg}$ in $0.3 \mathrm{~mL}$ saline $/ 100 \mathrm{~g}$ body weight $n=5$ ), as well as SCH58261 (first injection; i.p. $0.5 \mathrm{mg} / \mathrm{kg}$ in $0.3 \mathrm{~mL} \mathrm{10 \%} \mathrm{DMSO} \mathrm{solution/100} \mathrm{g} \mathrm{body} \mathrm{weight)} \mathrm{with} \mathrm{LPS}$ (second injection; $50 \mu \mathrm{g} / \mathrm{kg}$ in $0.3 \mathrm{~mL}$ saline $/ 100 \mathrm{~g}$ body weight $n=5$ ) were used in groups 2 and 3 , respectively.

After control periods, rats in groups 4, 5, and 6 were fed with KEKS food for 9 consecutive days (KEKS days) (Figure 1) and were i.p. injected by $0.3 \mathrm{~mL}$ saline $/ 100 \mathrm{~g}$ body weight (first injection) and by same injections (second injection; $0.3 \mathrm{~mL}$ saline $/ 100 \mathrm{~g}$ body weight, $30 \mathrm{~min}$ later) between the first and eighth days followed by EEG recording. It was previously demonstrated that KEKS food decreased both the number of spontaneously developed SWDs and LPS-generated increase in SWD number between 6-9 days of treatment [19]. However, to strengthen the beneficial effect of KEKS food on LPS-induced enhancement of the SWD number [19], animals in group $4(n=6)$ were injected with $0.3 \mathrm{~mL}$ $10 \%$ DMSO solution/100 g body weight (first injection) and, 30 min later, with LPS (second injection; $50 \mu \mathrm{g} / \mathrm{kg}$ in $0.3 \mathrm{~mL}$ saline $/ 100 \mathrm{~g}$ body weight) on the ninth day of KEKS food treatment. Moreover, to investigate the putative effects of combined administration of DPCPX with LPS and SCH58261 with LPS on the SWD number in KEKS-treated animals, in a recent study, rats (group 5 and group 6) received two i.p. injections on the ninth day of KEKS food treatment (these injections were similar to injections used in group 2 and group 3 on the fourth day of the experiments). Namely, in group $5(n=6)$, first i.p. injection (0.3 mL 10\% DMSO solution/100 g body weight) contained DPCPX $(0.2 \mathrm{mg} / \mathrm{kg})$, whereas the second injection contained LPS ( $50 \mu \mathrm{g} / \mathrm{kg}$ in $0.3 \mathrm{~mL}$ saline $/ 100 \mathrm{~g}$ body weight). In group $6(n=6)$, the first i.p. injection was $0.5 \mathrm{mg} / \mathrm{kg} \mathrm{SCH} 58261$ (in $0.3 \mathrm{~mL} 10 \%$ DMSO solution $/ 100 \mathrm{~g}$ body weight), whereas the second i.p. injection contained $50 \mu \mathrm{g} / \mathrm{kg}$ LPS (in $0.3 \mathrm{~mL}$ saline/100 g body weight). EEGs were recorded every day. As it has been demonstrated previously that KEKS food alone decreased the SWD number [19], whereas i.p. $0.2 \mathrm{mg} / \mathrm{kg}$ DPCPX and i.p. $0.5 \mathrm{mg} / \mathrm{kg}$ SCH58261 alone did not change the SWD number in $\mathrm{WAG} / \mathrm{Rij}$ rats $[11,31]$, these experiments were not carried out again in this study.

\subsection{Measuring the Level of Blood Glucose and R- $\beta H B$, and Body Weight}

Blood was taken from the tail vein of rats. We used a glucose and ketone monitoring system (Precision Xtra ${ }^{\mathrm{TM}}$, Abbott Laboratories, Irving, TX, USA) to measure the blood glucose $(\mathrm{mg} / \mathrm{dL})$ and $\beta \mathrm{HB}(\mathrm{R}-\beta \mathrm{HB} ; \mathrm{mmol} / \mathrm{L})$ levels $[2,11]$. This equipment only detects blood levels of R- $\beta \mathrm{HB}$. Consequently, the total blood ketone levels (R- $\beta \mathrm{HB}+\mathrm{L}-\beta \mathrm{HB}+$ $A c A c+$ acetone) would be higher than was detected in this study. Blood glucose and $\mathrm{R}-\beta \mathrm{HB}$ levels were measured on the third control day (control) and on the first and the ninth days of KEKS food treatment (groups 4-6). We also measured the body weight of rats before KEKS food treatment began (third control day, control) and after the last (ninth) KEKS administration day (groups 4-6).

\subsection{Statistical Analysis}

It was previously demonstrated that administration of EKSs (such as KE and KEKS food), i.p. LPS (50 $\mu \mathrm{g} / \mathrm{kg})$, DPCPX $(0.2 \mathrm{mg} / \mathrm{kg})$ and SCH58261 $(0.5 \mathrm{mg} / \mathrm{kg})$ had no influence on sleep-waking stages, average SWD time, and discharge frequency within SWDs in WAG/Rij rats $[11,19,23,28,31,34]$. Thus, in a recent study we focused on SWD number alteration generated by LPS (i.p. $50 \mu \mathrm{g} / \mathrm{kg}$ ) alone (group 1), by combined administration of DPCPX (i.p. $0.2 \mathrm{mg} / \mathrm{kg}$ ) with LPS (i.p. $50 \mu \mathrm{g} / \mathrm{kg}$ ) (group 2), SCH58261 (i.p. $0.5 \mathrm{mg} / \mathrm{kg}$ ) with LPS (i.p. $50 \mu \mathrm{g} / \mathrm{kg}$ ) (group 3) and KEKS food with LPS (i.p. $50 \mu \mathrm{g} / \mathrm{kg}$ ) (group 4). However, until now we had no data on the presumptive effects of combined administration of KEKS food with DPCPX and LPS, as well as KEKS food with SCH58261 and LPS (groups 5 and 6, respectively) not only on the SWD number, but also on SWD time. Thus, in relation 
to groups 5 and 6 , the average SWD time and total SWD time were also investigated on the ninth KEKS treatment day between 30-90 min.

All results were expressed as means \pm SEM (standard error of the mean). The pretreatment control SWD numbers (groups 1-6) and average SWD time (groups 5 and 6) were the grand average counted from the results of control days (three-day control period). In relation to the blood $\mathrm{R}-\beta \mathrm{HB}$ and glucose level, as well as body weight, the results were counted from the values determined on the last (third) control days. For data analysis, GraphPad PRISM 9 software was used. Significance was determined by one- or two-way analysis of variance (ANOVA), Tukey's multiple comparisons test, and Šídák's multiple comparisons test [2]. Statistical significance was considered at $p<0.05$.

\section{Results}

3.1. Effect of Combined Administration of DPCPX with LPS and SCH58261 with LPS on LPS-Evoked Increase in SWD Number

It has been previously demonstrated [23,34] that i.p. LPS $(50 \mu \mathrm{g} / \mathrm{kg})$ alone significantly enhanced the SWD number (group 1; Figure 2A; Table 1) between 30 and 150 min compared to the control. Combined administration of DPCPX $(0.2 \mathrm{mg} / \mathrm{kg})$ with LPS $(50 \mu \mathrm{g} / \mathrm{kg})$ (group 2) and SCH58261 (0.5 mg/kg) with LPS (50 $\mathrm{\mu g} / \mathrm{kg}$ ) (group 3) did not change the LPS-generated increase in SWD number (Figure 2B,C; Table 1).

Table 1. Effect of LPS alone, and combined administration of DPCPX with LPS and SCH58261 with LPS on SWD number.

\begin{tabular}{|c|c|c|c|c|c|c|}
\hline \multirow{3}{*}{ Treatments } & \multicolumn{2}{|c|}{ Figure 2A (Group 1) } & \multicolumn{2}{|c|}{ Figure 2B (Group 2) } & \multicolumn{2}{|c|}{ Figure 2C (Group 3) } \\
\hline & \multicolumn{6}{|c|}{ SWD Number (Mean \pm SEM; Level of Significance $/ p$-Value) } \\
\hline & 30-90 min & 90-150 min & $30-90 \mathrm{~min}$ & 90-150 min & $30-90 \mathrm{~min}$ & 90-150 min \\
\hline Control (CON) & $29.8 \pm 3.85$ & $29.3 \pm 3.71$ & $25.3 \pm 2.84$ & $27.7 \pm 3.79$ & $33.8 \pm 3.23$ & $28.0 \pm 2.74$ \\
\hline LPS $(50 \mu \mathrm{g} / \mathrm{kg})$ & $\begin{array}{c}66.4 \pm 6.31 \\
* * * * /<0.0001\end{array}$ & $\begin{array}{l}88.0 \pm 5.55 \\
* * * * /<0.0001\end{array}$ & - & - & - & - \\
\hline $\begin{array}{l}\text { DPCPX }(0.2 \mathrm{mg} / \mathrm{kg}) \\
+\mathrm{LPS}(50 \mu \mathrm{g} / \mathrm{kg})\end{array}$ & - & - & $\begin{array}{l}52.8 \pm 6.78 \\
* * /<0.0037\end{array}$ & $\begin{array}{c}77.6 \pm 4.71 \\
* * * * /<0.0001\end{array}$ & - & - \\
\hline $\begin{array}{c}\text { SCH58261 } \\
(0.5 \mathrm{mg} / \mathrm{kg})+\mathrm{LPS} \\
(50 \mu \mathrm{g} / \mathrm{kg})\end{array}$ & - & - & - & - & $\begin{array}{l}64.5 \pm 6.09 \\
* * * / 0.0009\end{array}$ & $\begin{array}{l}82.0 \pm 6.66 \\
* * * * /<0.0001\end{array}$ \\
\hline
\end{tabular}

Abbreviations: CON, control; DPCPX, 1,3-dipropyl-8-cyclopentylxanthine; i.p., intraperitoneal; LPS, lipopolysaccharide; SCH582361, 7-(2-phenylethyl)-5-amino-2-(2-furyl)-pyrazolo-[4,3-e]-1,2,4-triazolo[1,5-c]pyrimidine; SWD, spike-wave discharge. ${ }^{* *}: p<0.01,{ }^{* * *}: p<0.001$ and ${ }^{* * * *}: p<0.0001$. 

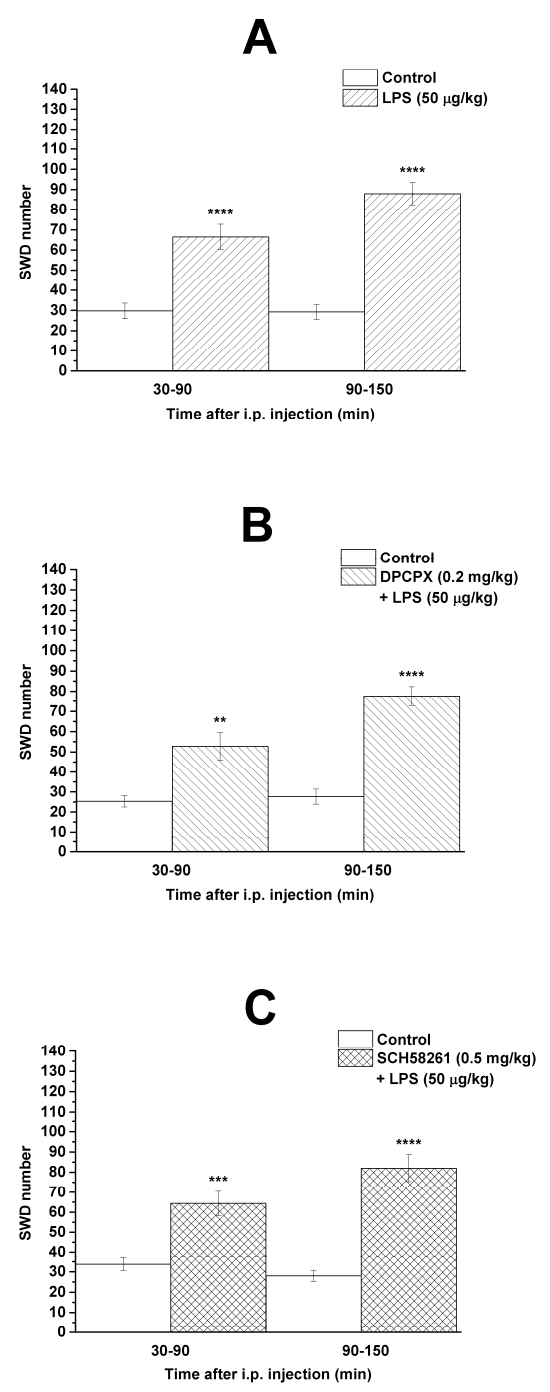

Figure 2. Effect of LPS (50 $\mu \mathrm{g} / \mathrm{kg})$ alone (A) and combined administration of DPCPX $(0.2 \mathrm{mg} / \mathrm{kg})$ with LPS (B) and SCH58261 (0.5 mg/kg) with LPS (C) on SWD number (group 1, group 2 and group 3, respectively). Abbreviations: DPCPX, 1,3-dipropyl-8-cyclopentylxanthine; i.p., intraperitoneal; LPS, lipopolysaccharide; SCH582361, 7-(2-phenylethyl)-5-amino-2-(2-furyl)-pyrazolo-[4,3-e]-1,2,4triazolo[1,5-c]pyrimidine; SWD, spike-wave discharge. ${ }^{* *}: p<0.01,{ }^{* * *}: p<0.001$ and ${ }^{* * * *}: p<0.0001$.

3.2. Effect of DPCPX and SCH58261 on KEKS Treatment-Evoked Decrease in SWD Number after LPS Administration

As it was demonstrated previously, KEKS-supplemented food abolished the influence of i.p. LPS (50 $\mu \mathrm{g} / \mathrm{kg})$ alone on SWD number [23,34] (Figure 2A) between 30 and $150 \mathrm{~min}$ on the ninth KEKS day [19] (group 4; Figure 3A; Table 2), compared to control levels. Nevertheless, on the ninth day of KEKS food administration, when this treatment was combined with i.p. DPCPX $(0.2 \mathrm{mg} / \mathrm{kg})$ and LPS $(50 \mu \mathrm{g} / \mathrm{kg})$ (group 5; Figure 3B; Table 2), the SWD number significantly increased, compared to the control. Thus, administration of DPCPX abolished the alleviating effect of KEKS food on the LPS-evoked increase in SWD number (Figure 3A,B). Combined administration of SCH58261 $(0.5 \mathrm{mg} / \mathrm{kg}$ ) and LPS $(50 \mu \mathrm{g} / \mathrm{kg}$ ) with KEKS food (on the ninth day of KEKS food administration) was not able to change the beneficial effect of KEKS food on the LPS-generated increase in SWD number between 30 and 90 min (group 6; Figure 3C; Table 2). Nevertheless, SCH58261 only decreased, but did not abolish the KEKS food-generated beneficial effect on the LPS-evoked increase in SWD number between 90 and 150 min on the ninth KEKS food administration day (group 6; Figure 3C; Table 2). 

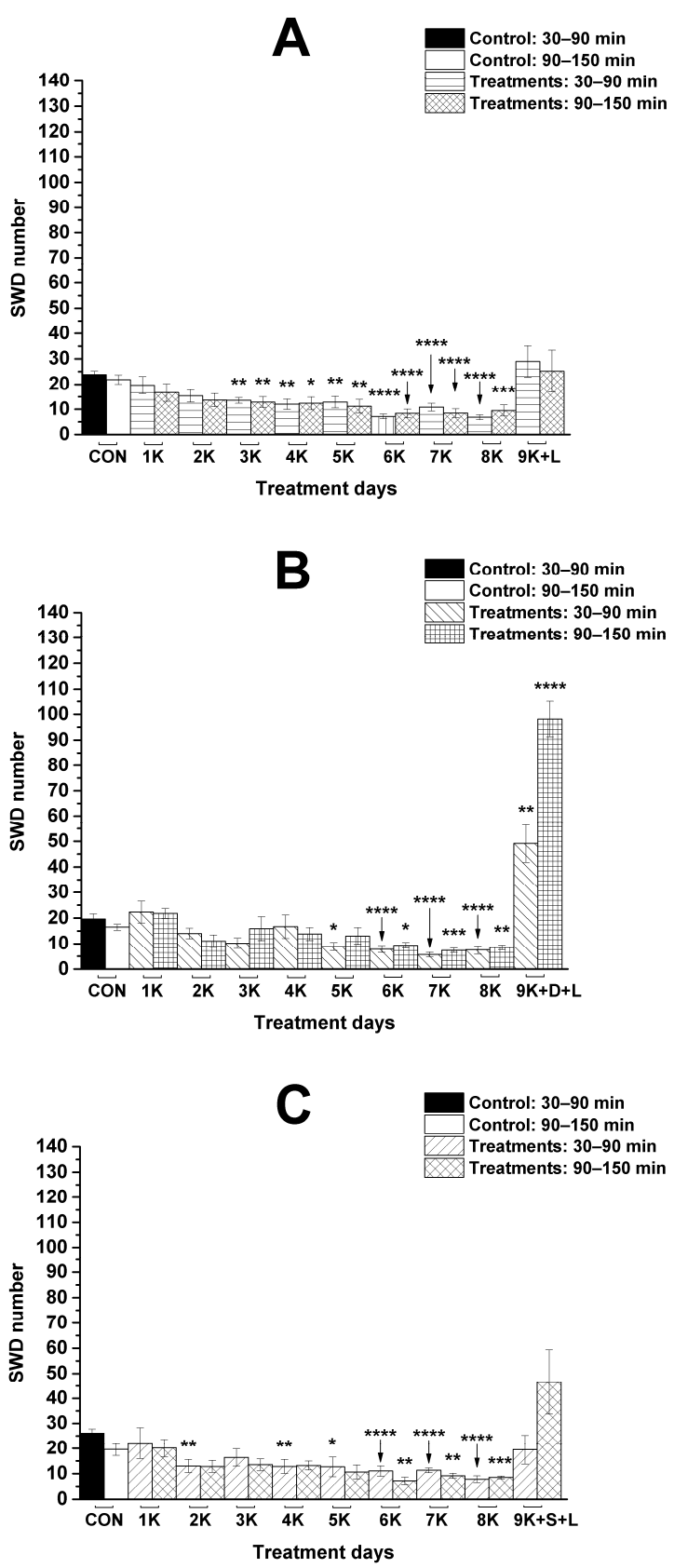

Figure 3. Influence of combined administration of KEKS-supplemented food (paste-like standard rodent chow containing 10\% ketone ester/KE, 10\% ketone salt/KS and 1\% saccharin) with LPS $(50 \mu \mathrm{g} / \mathrm{kg})(\mathbf{A})$, with DPCPX $(0.2 \mathrm{mg} / \mathrm{kg})$ and LPS (B) and with SCH58261 $(0.5 \mathrm{mg} / \mathrm{kg})$ and LPS (C) on SWD number (groups 4, 5, and 6, respectively). Abbreviations: $1 \mathrm{~K}$, first day of KEKS food administration, $2 \mathrm{~K}$, second day of KEKS food administration and so on; $9 \mathrm{~K}+\mathrm{D}+\mathrm{L}$, 9 th day of KEKS food administration and co-administration of i.p. DPCPX $(0.2 \mathrm{mg} / \mathrm{kg})$ and LPS $(50 \mu \mathrm{g} / \mathrm{kg}) ; 9 \mathrm{~K}+$ $\mathrm{L}$, 9th day of KEKS food administration and co-administration of i.p. LPS (50 $\mu \mathrm{g} / \mathrm{kg}) ; 9 \mathrm{~K}+\mathrm{S}+\mathrm{L}$, 9th day of KEKS food administration and co-administration of i.p. SCH58261 $(0.5 \mathrm{mg} / \mathrm{kg})$ and LPS $(50 \mu \mathrm{g} / \mathrm{kg})$; CON, control; SWD, spike-wave discharge. * $p<0.05,{ }^{* *}: p<0.01,{ }^{* * *}: p<0.001$ and ${ }^{* * * *}$ : $p<0.0001$. 
Table 2. Influence of KEKS-supplemented food (paste-like standard rodent chow containing 10\% ketone ester $/ \mathrm{KE}$, 10\% ketone salt/KS and 1\% saccharin) on SWD number between first $(1 \mathrm{~K})$ and 8 th $(8 \mathrm{~K})$ day of administration and on 9 th day of KEKS food (9K) administration combined with i.p. LPS (L) $(9 K+$ L), i.p. DPCPX (D) and LPS (9K + D + L), as well as i.p. SCH58261 (S) and LPS (9K + S + L), compared to control (CON).

\begin{tabular}{|c|c|c|c|c|c|c|}
\hline \multirow{3}{*}{ Treatments } & \multicolumn{2}{|c|}{ Figure 3A (Group 4) } & \multicolumn{2}{|c|}{ Figure 3B (Group 5) } & \multicolumn{2}{|c|}{ Figure 3C (Group 6) } \\
\hline & \multicolumn{6}{|c|}{ SWD Number (Mean \pm SEM; Level of Significance $/ p$-Value) } \\
\hline & $30-90 \mathrm{~min}$ & 90-150 min & $30-90 \mathrm{~min}$ & 90-150 min & $30-90 \mathrm{~min}$ & 90-150 min \\
\hline Control (CON) & $23.8 \pm 1.36$ & $21.9 \pm 1.83$ & $19.7 \pm 1.98$ & $16.4 \pm 1.18$ & $26.2 \pm 1.61$ & $19.6 \pm 2.44$ \\
\hline $\begin{array}{l}\text { 1st KEKS treatment } \\
(1 \mathrm{~K})\end{array}$ & $\begin{array}{c}19.7 \pm 3.38 \\
\mathrm{~ns} / 0.6999\end{array}$ & $\begin{array}{c}16.7 \pm 3.56 \\
\mathrm{~ns} / 0.5327\end{array}$ & $\begin{array}{c}22.3 \pm 4.19 \\
\mathrm{~ns} / 0.8824\end{array}$ & $\begin{array}{c}21.8 \pm 1.89 \\
\mathrm{~ns} / 0.4668\end{array}$ & $\begin{array}{c}22.1 \pm 6.18 \\
\mathrm{~ns} / 0.8818\end{array}$ & $\begin{array}{c}20.2 \pm 3.46 \\
\mathrm{~ns} / 0.9996\end{array}$ \\
\hline $\begin{array}{l}\text { 2nd KEKS treatment } \\
\qquad(2 \mathrm{~K})\end{array}$ & $\begin{array}{c}15.3 \pm 2.49 \\
\mathrm{~ns} / 0.0522\end{array}$ & $\begin{array}{c}13.7 \pm 2.70 \\
\mathrm{~ns} / 0.0623\end{array}$ & $\begin{array}{l}14.0 \pm 2.07 \\
\mathrm{~ns} / 0.2113\end{array}$ & $\begin{array}{c}11.0 \pm 2.46 \\
\mathrm{~ns} / 0.2397\end{array}$ & $\begin{array}{c}13.0 \pm 2.58 \\
* * / 0.0030\end{array}$ & $\begin{array}{c}12.8 \pm 2.34 \\
\mathrm{~ns} / 0.1862\end{array}$ \\
\hline $\begin{array}{c}\text { 3rd KEKS treatment } \\
(3 \mathrm{~K})\end{array}$ & $\begin{array}{l}13.5 \pm 1.18 \\
* * / 0.0015\end{array}$ & $\begin{array}{l}12.8 \pm 2.14 \\
* * / 0.0051\end{array}$ & $\begin{array}{c}10.2 \pm 1.99 \\
\text { ns } / 0.1100\end{array}$ & $\begin{array}{c}15.8 \pm 4.71 \\
\mathrm{~ns} / 0.9986\end{array}$ & $\begin{array}{c}16.3 \pm 3.38 \\
\mathrm{~ns} / 0.0526\end{array}$ & $\begin{array}{c}13.5 \pm 2.25 \\
\mathrm{~ns} / 0.3380\end{array}$ \\
\hline $\begin{array}{c}\text { 4th KEKS treatment } \\
(4 \mathrm{~K})\end{array}$ & $\begin{array}{l}12.0 \pm 2.03 \\
* * / 0.0021\end{array}$ & $\begin{array}{l}12.3 \pm 2.51 \\
* / 0.0132\end{array}$ & $\begin{array}{c}16.7 \pm 4.55 \\
\mathrm{~ns} / 0.8773\end{array}$ & $\begin{array}{c}13.8 \pm 2.52 \\
\mathrm{~ns} / 0.9141\end{array}$ & $\begin{array}{c}12.8 \pm 2.79 \\
* * / 0.0020\end{array}$ & $\begin{array}{c}13.2 \pm 1.78 \\
\mathrm{~ns} / 0.2007\end{array}$ \\
\hline $\begin{array}{c}\text { 5th KEKS treatment } \\
(5 \mathrm{~K})\end{array}$ & $\begin{array}{l}12.8 \pm 2.30 \\
* * / 0.0073\end{array}$ & $\begin{array}{l}11.2 \pm 2.70 \\
* * / 0.0089\end{array}$ & $\begin{array}{l}8.8 \pm 1.56 \\
* / 0.0104\end{array}$ & $\begin{array}{c}13.0 \pm 3.34 \\
\mathrm{~ns} / 0.6795\end{array}$ & $\begin{array}{c}12.7 \pm 3.84 \\
* / 0.0130\end{array}$ & $\begin{array}{c}10.7 \pm 2.75 \\
\mathrm{~ns} / 0.1382\end{array}$ \\
\hline $\begin{array}{l}\text { 6th KEKS treatment } \\
(6 \mathrm{~K})\end{array}$ & $\begin{array}{c}7.2 \pm 0.95 \\
* * * * /<0.0001\end{array}$ & $\begin{array}{c}8.3 \pm 1.78 \\
* * * * /<0.0001\end{array}$ & $\begin{array}{c}7.8 \pm 1.42 \\
* * * * /<0.0001\end{array}$ & $\begin{array}{l}9.3 \pm 1.09 \\
* / 0.0123\end{array}$ & $\begin{array}{c}11.0 \pm 2.01 \\
* * * * /<0.0001\end{array}$ & $\begin{array}{l}7.2 \pm 1.45 \\
* * / 0.0010 \\
\end{array}$ \\
\hline $\begin{array}{c}\text { 7th KEKS treatment } \\
(7 \mathrm{~K})\end{array}$ & $\begin{array}{l}10.8 \pm 1.52 \\
* * * * /<0.0001\end{array}$ & $\begin{array}{c}8.5 \pm 1.73 \\
* * * * /<0.0001\end{array}$ & $\begin{array}{c}5.7 \pm 0.92 \\
* * * * /<0.0001\end{array}$ & $\begin{array}{l}7.3 \pm 0.92 \\
* * * / 0.0005\end{array}$ & $\begin{array}{c}11.3 \pm 0.96 \\
* * * * /<0.0001\end{array}$ & $\begin{array}{l}9.2 \pm 1.01 \\
* * / 0.001\end{array}$ \\
\hline $\begin{array}{l}\text { 8th KEKS treatment } \\
\qquad(8 \mathrm{~K})\end{array}$ & $\begin{array}{c}6.8 \pm 1.01 \\
* * * * *<0.0001\end{array}$ & $\begin{array}{l}9.5 \pm 2.20 \\
* * * / 0.0002 \\
\end{array}$ & $\begin{array}{c}7.5 \pm 1.57 \\
* * * * /<0.0001\end{array}$ & $\begin{array}{l}8.5 \pm 0.96 \\
* * / 0.0054\end{array}$ & $\begin{array}{c}7.8 \pm 1.30 \\
* * * * /<0.0001\end{array}$ & $\begin{array}{r}8.5 \pm 0.56 \\
* * * / 0.0005\end{array}$ \\
\hline $\begin{array}{l}\text { 9th KEKS treatment } \\
\qquad(9 \mathrm{~K}+\mathrm{L})\end{array}$ & $\begin{array}{c}29.0 \pm 6.16 \\
\mathrm{~ns} / 0.8988\end{array}$ & $\begin{array}{c}25.2 \pm 8.26 \\
\mathrm{~ns} / 0.9712\end{array}$ & - & - & - & - \\
\hline $\begin{array}{c}\text { 9th KEKS treatment } \\
\quad(9 \mathrm{~K}+\mathrm{D}+\mathrm{L})\end{array}$ & - & - & $\begin{array}{l}49.2 \pm 7.31 \\
* * / 0.0032 \\
\end{array}$ & $\begin{array}{c}98.2 \pm 6.86 \\
* * * * *<00.0001\end{array}$ & - & - \\
\hline $\begin{array}{c}\text { 9th KEKS treatment } \\
(9 \mathrm{~K}+\mathrm{S}+\mathrm{L})\end{array}$ & - & - & - & - & $\begin{array}{l}19.5 \pm 5.71 \\
\mathrm{~ns} / 0.9117\end{array}$ & $\begin{array}{c}46.5 \pm 12.79 \\
\mathrm{~ns} / 0.0663\end{array}$ \\
\hline
\end{tabular}

Abbreviations: ns, non-significant; SWD, spike-wave discharge. ${ }^{*}: p<0.05,{ }^{* *}: p<0.01,{ }^{* * *}: p<0.001$ and ${ }^{* * *}: p<0.0001$.

After the combined i.p. administration of DPCPX $(0.2 \mathrm{mg} / \mathrm{kg})$ with LPS $(50 \mu \mathrm{g} / \mathrm{kg})$ and SCH58261 $(0.5 \mathrm{mg} / \mathrm{kg})$ with LPS $(50 \mu \mathrm{g} / \mathrm{kg})$ (groups 5 and 6 , respectively) on the ninth day of KEKS food administration, the average SWD time did not change significantly (control/KEKS food + DPCPX + LPS: $7.5 \pm 0.21 \mathrm{~s} / 7.6 \pm 0.33 \mathrm{~s}, p>0.9999$; control/KEKS food + SCH58261 + LPS: $7.6 \pm 0.42 \mathrm{~s} / 7.5 \pm 0.29 \mathrm{~s}, p>0.9999)$. As the average SWD duration did not change after these treatments and the SWD number significantly changed (increased) only after i.p. DPCPX + LPS (group 5; Figure 3B; Table 2), whereas the SWD number did not change significantly after i.p. SCH58261 + LPS (group 6; Figure 3C; Table 2) on the ninth KEKS food administration day, compared to the control, alterations in the total time of SWDs could be different in these two groups. Indeed, the total time of SWDs increased after the combined administration of DPCPX with LPS (control/KEKS food + DPCPX + LPS; $145.3 \pm 14.1 \mathrm{~s} / 372.1 \pm 60.9 \mathrm{~s}, p<0.0001)$, but the total time of SWDs did not change significantly after co-administration of SCH58261 with LPS (control/KEKS food + SCH58261 + LPS; $198.3 \pm 15.9 / 143.8 \pm 39.3 \mathrm{~s}, p=0.83$ ) on the ninth day of KEKS food treatment between 30 and $90 \mathrm{~min}$, compared to the control.

\subsection{KEKS-Generated Changes in Blood R- $\beta H B$ and Glucose Levels and Body Weight}

It was demonstrated that KEKS food treatment effectively increased the blood R- $\beta \mathrm{HB}$ level not only after the first KEKS food treatment, but also on the ninth day of KEKS food 
administration, independently of the combination of i.p. injections (LPS alone, DPCPX + LPS, SCH58261 + LPS; groups 4, 5, and 6; Figure 4A,C,E, respectively), compared to control levels. Nevertheless, the level of blood glucose was unchanged (groups 4, 5, and 6; Figure 4B,D,F, respectively) (Table 3).

A

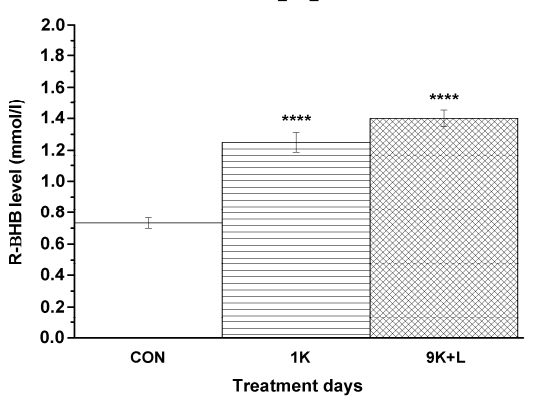

C

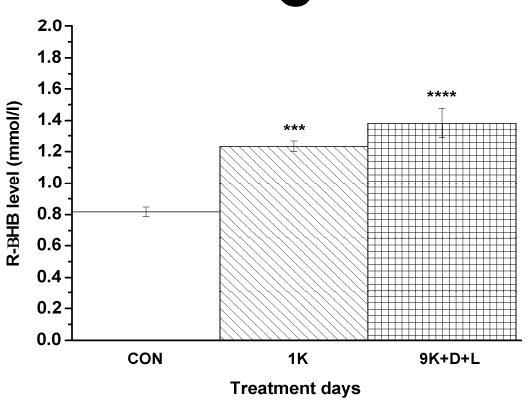

$\mathbf{E}$

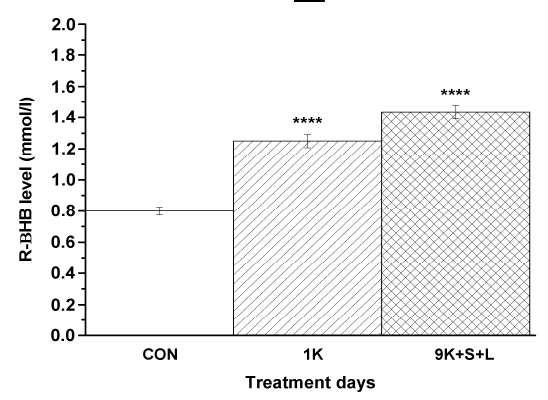

B

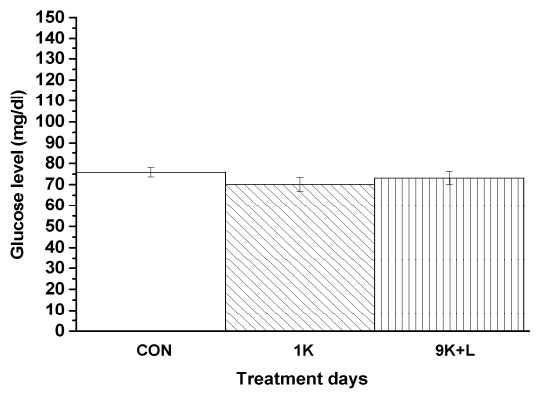

D

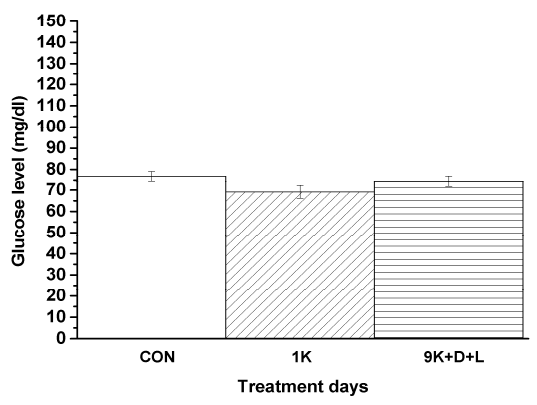

$\mathbf{F}$

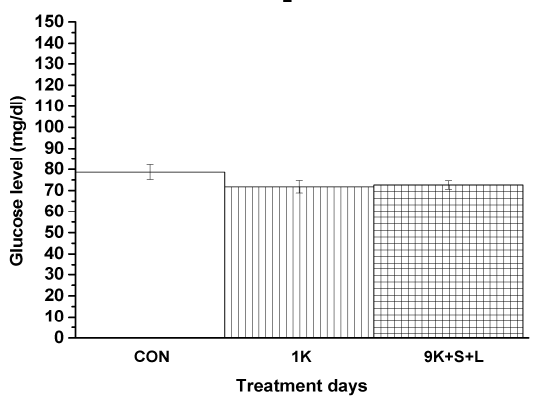

Figure 4. Changes in blood R- $\beta$ HB and glucose levels on the first day of KEKS-supplemented food ( $10 \%$ ketone ester $/ \mathrm{KE}, 10 \%$ ketone salt/KS and $1 \%$ saccharin in paste-like standard rodent chow) administration (1K; $(\mathbf{A}-\mathbf{F}))$ and on the ninth day of KEKS food administration combined with i.p. LPS $(50 \mu \mathrm{g} / \mathrm{kg})(9 \mathrm{~K}+\mathrm{L} ; \mathbf{A}, \mathbf{B})$, with i.p. DPCPX $(0.2 \mathrm{mg} / \mathrm{kg})$ and LPS $(9 \mathrm{~K}+\mathrm{D}+\mathrm{L} ; \mathbf{C}, \mathbf{D})$ and with i.p. SCH58261 $(0.5 \mathrm{mg} / \mathrm{kg})$ and LPS $(9 \mathrm{~K}+\mathrm{S}+\mathrm{L} ; \mathrm{E}$ and F), compared to the control (CON; groups 4, 5, and 6 , respectively). ${ }^{* *}: p<0.001$ and ${ }^{* * *}: p<0.0001$. 
Table 3. Influence of KEKS supplemented food (paste-like standard rodent chow containing 10\% ketone ester/KE, 10\% ketone salt/KS and 1\% saccharin) on blood R- $\beta \mathrm{HB}$ and glucose levels on first $(1 \mathrm{~K})$ day of administration and on 9 th day of KEKS food (K) administration combined with i.p. LPS (L) (9K + L), i.p. DPCPX (D) and LPS (9K + D + L), as well as i.p. SCH58261 (S) and LPS (9K + S + L), compared to control (CON).

\begin{tabular}{|c|c|c|c|c|c|c|}
\hline \multirow{3}{*}{ Treatments } & \multicolumn{2}{|c|}{ Figure 4A,B (Group 4) } & \multicolumn{2}{|c|}{ Figure $4 \mathrm{C}, \mathrm{D}$ (Group 5) } & \multicolumn{2}{|c|}{ Figure $4 \mathrm{E}, \mathrm{F}$ (Group 6) } \\
\hline & \multicolumn{6}{|c|}{ Blood Level of R- $\beta$ HB and Glucose (Mean \pm SEM; Level of Significance $/ p$-Value) } \\
\hline & $\begin{array}{c}\mathrm{R}-\beta \mathrm{HB} \\
(\mathrm{mmol} / \mathrm{L})\end{array}$ & $\begin{array}{l}\text { Glucose } \\
(\mathrm{mg} / \mathrm{dL})\end{array}$ & $\begin{array}{c}\mathrm{R}-\beta \mathrm{HB} \\
(\mathrm{mmol} / \mathrm{L})\end{array}$ & $\begin{array}{l}\text { glucose } \\
(\mathrm{mg} / \mathrm{dL})\end{array}$ & $\begin{array}{c}\mathrm{R}-\beta \mathrm{HB} \\
(\mathrm{mmol} / \mathrm{L})\end{array}$ & $\begin{array}{l}\text { Glucose } \\
(\mathrm{mg} / \mathrm{dL})\end{array}$ \\
\hline Control (CON) & $0.73 \pm 0.03$ & $75.83 \pm 2.23$ & $0.82 \pm 0.03$ & $76.83 \pm 2.27$ & $0.80 \pm 0.03$ & $78.67 \pm 3.49$ \\
\hline $\begin{array}{l}\text { first KEKS treatment } \\
\qquad(1 \mathrm{~K})\end{array}$ & $\begin{array}{l}1.25 \pm 0.06 \\
* * * * /<0.0001\end{array}$ & $\begin{array}{c}70.17 \pm 3.26 \\
\mathrm{~ns} / 0.3827\end{array}$ & $\begin{array}{l}1.23 \pm 0.03 \\
* * * / 0.0006\end{array}$ & $\begin{array}{c}69.17 \pm 3.03 \\
\text { ns } / 0.1336\end{array}$ & $\begin{array}{c}1.25 \pm 0.04 \\
* * * * /<0.0001\end{array}$ & $\begin{array}{c}71.83 \pm 2.94 \\
\mathrm{~ns} / 0.2445\end{array}$ \\
\hline $\begin{array}{l}\text { 9th KEKS treatment } \\
\qquad(9 \mathrm{~K}+\mathrm{L})\end{array}$ & $\begin{array}{c}1.40 \pm 0.05 \\
* * * * /<0.0001\end{array}$ & $\begin{array}{c}73.17 \pm 3.19 \\
\mathrm{~ns} / 0.7992\end{array}$ & - & - & - & - \\
\hline $\begin{array}{c}\text { 9th KEKS treatment } \\
\quad(9 \mathrm{~K}+\mathrm{D}+\mathrm{L})\end{array}$ & - & - & $\begin{array}{c}1.38 \pm 0.09 \\
* * * * /<0.0001\end{array}$ & $\begin{array}{c}74.33 \pm 2.57 \\
\mathrm{~ns} / 0.7842\end{array}$ & - & - \\
\hline $\begin{array}{c}9 \text { th KEKS treatment } \\
(9 \mathrm{~K}+\mathrm{S}+\mathrm{L})\end{array}$ & - & - & - & - & $\begin{array}{c}1.43 \pm 0.04 \\
* * * * /<0.0001\end{array}$ & $\begin{array}{c}72.67 \pm 1.98 \\
\mathrm{~ns} / 0.3296\end{array}$ \\
\hline
\end{tabular}

Abbreviations: R- $\beta$ HB, R-beta-hydroxybutyrate. ${ }^{* * *}: p<0.001$ and ${ }^{* * * *}: p<0.0001$.

The body weight of animals in the three KEKS treated groups (groups 4, 5, and 6) did not change significantly compared to the control (control/treated; group 4: $327.7 \pm 3.63$ $\mathrm{g} / 323.8 \pm 5.26 \mathrm{~g}, p=0.5062$; group 5: $334.7 \pm 5.37 \mathrm{~g} / 331.0 \pm 6.68 \mathrm{~g}, p=0.5344$; group 6: $326.2 \pm 6.56 \mathrm{~g} / 323.5 \pm 6.71 \mathrm{~g}, p=0.8599)$. Similarly to our previous study [19], food intake was not investigated in the recent study. Nevertheless, the unchanged body weight of animals in groups 4, 5, and 6 suggests that KEKS food treatment did not exert its influence on the SWD number and SWD time through insufficient food intake or calorie restriction.

\section{Discussion}

In this study, we further validated our previous result that KEKS-supplemented food (KEKS food) is able to decrease the LPS-induced increase in SWD number [19] and provided new evidence that this alleviating effect of KEKS food may be mediated by the adenosinergic system, likely through A1Rs.

It has been demonstrated that IL-1 $\beta$, LPS, and prostanoids (such as $\mathrm{PGE}_{2}$ ) can trigger cortical hyperexcitability $[22,25]$. Thus, LPS-generated inflammatory processes can intensify excitation in the hyperexcitable focal cortical zone (peri-oral region of the somatosensory cortex: cortical focus of absence epilepsy genesis) through proinflammatory cytokines in WAG/Rij rats, thereby increasing the SWD number [18,20,23,34] (Figure 2A). LPS has a role in the activation of NOD-like receptor pyrin domain 3 (NLRP3) inflammasome, TLR4 and release of IL-1 $\beta$ and TNF- $\alpha$ (tumor necrosis factor- $\alpha$ ) [22,37,38], whereas KEKS food can inhibit the NLRP3 inflammasome and release of proinflammatory cytokines (such as IL-1 $\beta$ ) through increased $\beta$ HB level (ketosis) $[16,39]$. Moreover, KEKS food-evoked increase in $\beta \mathrm{HB}$ levels can also inhibit the activity of different parts of signaling pathways via the TLR4, IL-1 receptor, TNF- $\alpha$, COX-2, and NF- $\mathrm{KB}$ (nuclear factor- $\mathrm{KB}$ ) through, for example, hydroxyl-carboxylic acid receptor 2 (HCAR2 receptor) [40-42]; therefore, it may decrease the SWD number in WAG/Rij rats. Indeed, KEKS food-evoked ketosis decreased the LPS-induced increase in SWD number likely through the inhibition of inflammatory processes in WAG/Rij rats [11,19] (Figure 3A).

Ketosis may increase the concentration of adenosine [30], and thereby can modulate the activity of adenosine receptors. It was also suggested that EKSs-generated alleviating effects on absence epileptic activity may be mediated through increased $\beta \mathrm{HB}$ level-evoked increase in adenosine level and A1R activity [11,19]. Indeed, EKSs-induced increase in $\beta H B$ level can increase the level of not only extracellular ATP, but also adenosine $[4,43,44]$. Thus, adenosine may evoke hyperpolarization of neuronal membranes and decrease neuronal 
activity through, for example, A1R-mediated opening of ATP-sensitive potassium channels and synaptic inhibition $[4,29,44,45]$ resulting in both moderate hyperexcitability in the cortical focus and a decreased SWD number in WAG/Rij rats. It was also demonstrated that the activation of A2ARs increased the SWD number in WAG/Rij rats [28,46], suggesting that A2ARs are not able to modulate the alleviating influence of EKSs-generated ketosis on the number of spontaneously developed SWDs in WAG/Rij rats [11].

It has been previously demonstrated that administration of a non-selective adenosine receptor antagonist theophylline (i.p. 5 and $10 \mathrm{mg} / \mathrm{kg}$ ) and i.p. $1 \mathrm{mg} / \mathrm{kg}$ SCH58261 decreased the SWD number $[46,47]$ in WAG/Rij rats. In another rat model of human absence epilepsy GAERS (Genetic Absence Epilepsy Rats from Strasbourg), similar results were demonstrated, where another non-selective adenosine receptor antagonist caffeine (i.p. 1, 2.5, 5 and $10 \mathrm{mg} / \mathrm{kg}$ ) decreased both the SWD number and total SWD time, and the A2AR antagonist DMPX (3,7-dimethyl-1-propargylxanthine; i.p. 0.15 and $0.3 \mathrm{mg} / \mathrm{kg}$ ) generated a modest decrease in the total SWD time [48]. It was also demonstrated that i.p. $0.5 \mathrm{mg} / \mathrm{kg}$ DPCPX increased the SWD number in WAG/Rij rats [11], whereas a different A1R antagonist 8-CPT (8-cyclopentyl-1,3-dimethylxanthine; i.p. 0.625 and $3 \mathrm{mg} / \mathrm{kg}$ ) decreased the SWD number in GAERS [48]. Based on the above results, we can conclude that A1Rs are able to generate a different modulatory influence on absence epilepsy genesis in these models. Consequently, theoretically, ketosis-generated effects on a number of spontaneously developed SWDs may be different in WAG/Rij rats and GAERS, at least through the adenosinergic system. Indeed, despite that, a ketogenic diet increased the blood $\beta \mathrm{HB}$ level in GAERS, it was not able to alter the SWD number [49]. However, new studies are needed to reveal the reason(s) of the different influences of A1R antagonism on absence epileptic activity in WAG/Rij rats and GAERS (e.g., investigation of A1R expression and distribution in brain areas implicated in absence epilepsy genesis in both rat strains).

It has been demonstrated that adenosine is a key anti-inflammatory mediator [50]. In the central nervous system, adenosine exerts its effects on inflammatory processes mainly through A1Rs and A2ARs [51]. A1Rs and A2ARs are expressed in astrocytes, oligodendrocytes, and microglia modulating inflammatory processes [50,52]. For example, both an A1R agonist (2-chloro- $\mathrm{N}^{6}$-cyclopentyl-2'-deoxyadenosine) and an A2AR antagonist (8-chloro-9-ethyl-2-phenethoxyadenine) alleviated the neuroinflammation (which inflammation was evoked by a pro-inflammatory cytokine cocktail, containing TNF- $\alpha$, IL-1 $\beta$, and interferon-gamma/IFN- $\gamma$ ). Moreover, this A2AR antagonist also showed antioxidant properties in mixed glial cells and after intracerebroventricular injection of $10 \mu \mathrm{g}$ LPS [51]. These results suggest that activation of A1Rs and inhibition of A2ARs may evoke alleviating (anti-inflammatory) effects on neuroinflammatory processes. Indeed, activation of A1Rs decreased both the astrocyte proliferation and the excessive activation of microglial cells, thereby attenuating neuroinflammation, whereas an increase in microglial activity and neuroinflammation was demonstrated in A1R knockout mice [53-55]. Moreover, A1R activation can attenuate LPS-induced inflammation through inhibition of hypoxia-inducible factor 1 accumulation, thereby downregulation of genes involved in inflammatory processes (e.g., inducible nitric oxide synthase, iNOS) in astrocytes [56]. Activation of A1Rs may also mitigate the harmful influence of ROS (reactive oxygen species) on brain cells [26]. It has also been demonstrated that administration of SCH58261 reduced the level of IL-1 $\beta$, IL-6, iNOS, and TNF $\alpha$, whereas an A2AR agonist (CGS21680) increased the level of cytokines in microglial cells [57]. A2AR antagonists (e.g., SCH58261) decreased the LPS-evoked activation of microglia and secretion of IL- $1 \beta$ in microglial cells $[58,59]$. A2AR activation can increase the activation and proliferation of astrocytes [60,61]. Moreover, activation of A2ARs in microglial cells can increase not only the activity of nitric oxide synthase (NOS) and the level of COX2 expression (one of the enzymes of prostaglandin/PGE synthesis), but also the release of cytokines, $\mathrm{PGE}_{2}$, and $\mathrm{NO}[62,63]$. Consequently, activation of A1Rs may attenuate, whereas activation of A2ARs may enhance the neuroinflammatory processes and their pathological consequences $[56,59,64]$. All of the above results suggest that KEKS food-evoked decrease in an LPS-generated increase in SWD number are likely 
modulated by A1Rs, at least in WAG/Rij rats (Figure 3A,B). However, it was also suggested that A2ARs can also evoke peripheral anti-inflammatory effects [50,65]; adenosine may decrease LPS-induced cytokine production through A2ARs [27]; activation of A2ARs may inhibit the iNOS expression and NO production [66]; and inhibition of A2ARs did not abolish, but somewhat decreased the KEKS food-evoked alleviating effect on LPS-generated increase in SWD number between 90 and $150 \mathrm{~min}$ (Figure 3C). Thus, the beneficial effect of KEKS food-generated A2AR activation on LPS-induced neuroinflammation thereby on increased SWD number cannot be excluded entirely.

\section{Conclusions}

Our results strengthened the potential of ketogenic supplements, such as KEKSsupplemented food, for the treatment of epilepsy through the inhibition of inflammatory pathways. In relation to the mechanism of action, it is likely that KEKS-induced ketosis modulated A1Rs to alleviate the neuroinflammation-induced increase in SWD number. Thus, theoretically, co-administration of EKSs and different modulators of adenosinergic systems (e.g. adenosine receptors) may allow us to develop promising therapeutic tools in the treatment of not only epilepsy, but also inflammation-evoked neurodegenerative diseases. However, further studies are needed to reveal molecular signaling between EKSsevoked alleviating effects on the SWD number, neuroinflammation, and the adenosinergic system in different cells and brain areas implicated in absence epilepsy genesis.

Author Contributions: Conceptualization, B.B. and Z.K.; Data curation, B.B. and C.A.; Formal analysis, C.A.; Funding acquisition, D.P.D. and Z.K.; Investigation, B.B.; Methodology, B.B.; Project administration, C.A. and Z.K.; Resources, D.P.D. and Z.K.; Supervision, Z.K.; Writing-original draft, B.B. and C.A.; Writing-review and editing, D.P.D. and Z.K. All authors have read and agreed to the published version of the manuscript.

Funding: This work was supported by ELTE BDPK Excellence Program 12/2020 (to Zsolt Kovács), Ketone Technologies LLC and ONR Grant N000141310062 (to Dominic P. D'Agostino).

Institutional Review Board Statement: The study was approved by Animal Care and Experimentation Committee of the ELTE Savaria University Centre (protocol code VA/ÉBNTF02/85-8, 2016).

Informed Consent Statement: Not applicable.

Data Availability Statement: The data presented in this study are available on request from the corresponding author.

Conflicts of Interest: International Patent \# PCT/US2014/031237, University of South Florida, D.P. D'Agostino, S. Kesl, P. Arnold, “Compositions and Methods for Producing Elevated and Sustained Ketosis". Patent: US 10,980,764 B1, C. Ari, D.P.D'Agostino, “Exogenous ketone supplements for reducing anxiety-related behavior"; Ari, C., Arnold P., D'Agostino, D.P. Technology Title: "Exogenous Ketone Supplementation Improved Motor Function in Sprague-Dawley Rats." USF Ref. No: 16A019; Ari, C., Arnold P., D’Agostino, D.P. Technology Title: "Lowering of Blood Glucose in Exercising and Non-Exercising Rats Following Administration of Exogenous Ketones and Ketone Formulas." USF Ref. No: 16A049; Ari, C., Arnold P., D’Agostino, D.P. Technology Title: "Neuroregeneration improved by ketone." USF Ref. No: 16B128 (provisional patent); Patent: US 10,945,975 B2:Ari, C., D'Agostino, D.P. Dean, J.B. Technology Title: "Delaying latency to seizure by combinations of ketone supplements." D.P. D'Agostino and C. Ari are co-owners of the company Ketone Technologies LLC, and C. Ari is owner of Fortis World LLC. These interests have been reviewed and managed by the University in accordance with its Institutional and Individual Conflict of Interest policies. All authors declare that there are no additional conflict of interest. 


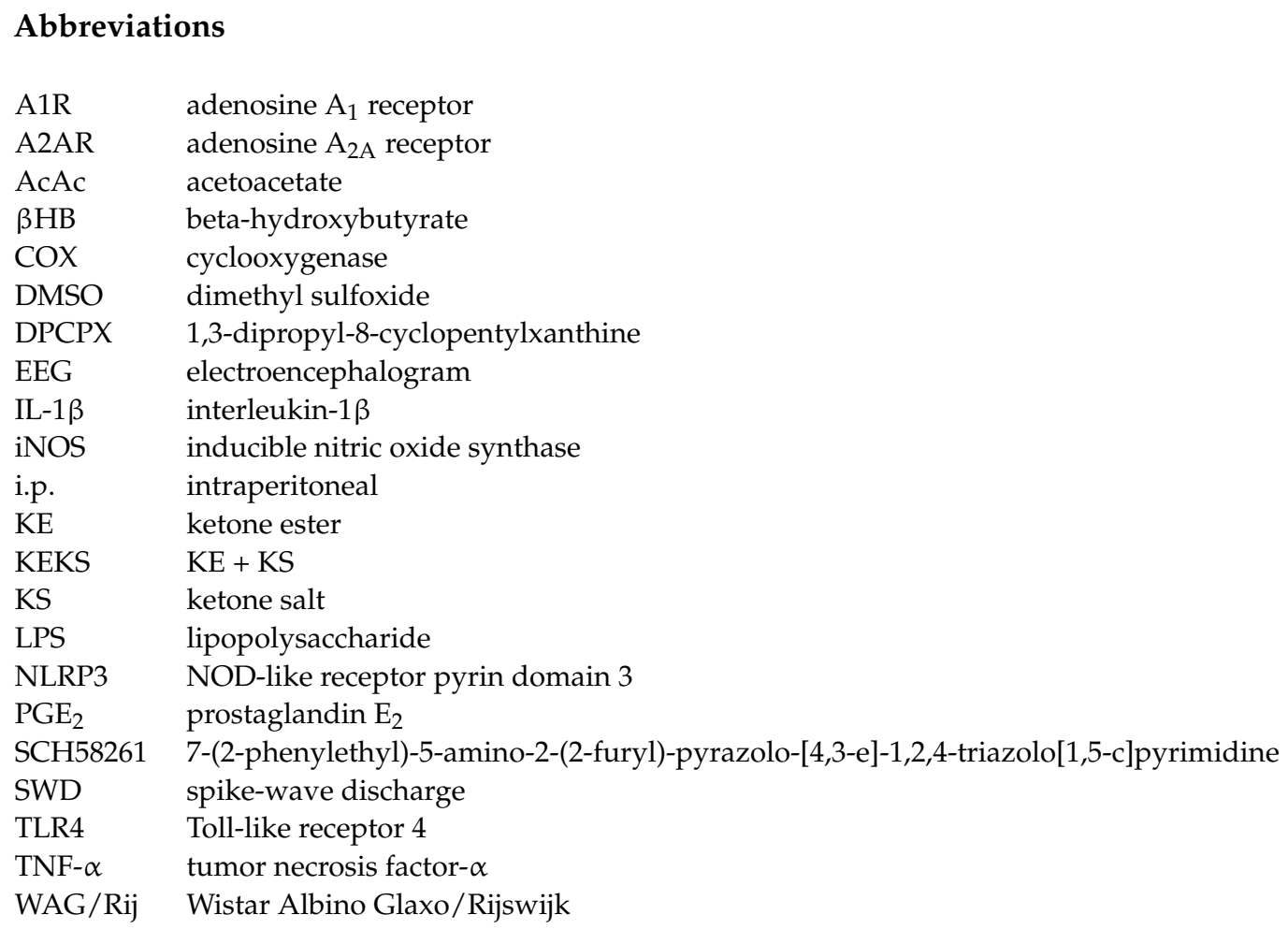

\section{References}

1. Brunengraber, H. Potential of ketone body esters for parenteral and oral nutrition. Nutrition 1997, 13, 233-235. [CrossRef]

2. Ari, C.; Kovács, Z.; Juhasz, G.; Murdun, C.; Goldhagen, C.R.; Koutnik, A.M.; Poff, A.M.; Kesl, S.L.; D’ Agostino, D.P. Exogenous ketone supplements reduce anxiety-related behavior in Sprague-Dawley and Wistar Albino Glaxo/Rijswijk rats. Front. Mol. Neurosci. 2016, 9, 137. [CrossRef]

3. Kesl, S.L.; Poff, A.M.; Ward, N.P.; Fiorelli, T.N.; Ari, C.; Van Putten, A.J.; Sherwood, J.W.; Arnold, P.; D'Agostino, D.P. Effects of exogenous ketone supplementation on blood ketone, glucose, triglyceride, and lipoprotein levels in Sprague-Dawley rats. Nutr. Metab. (Lond.) 2016, 13, 9. [CrossRef]

4. Achanta, L.B.; Rae, C.D. $\beta$-Hydroxybutyrate in the Brain: One Molecule, Multiple Mechanisms. Neurochem. Res. 2017, 42, 35-49. [CrossRef] [PubMed]

5. Newman, J.C.; Verdin, E. Ketone bodies as signaling metabolites. Trends Endocrinol. Metab. 2014, 25, 42-52. [CrossRef]

6. Brownlow, M.L.; Jung, S.H.; Moore, R.J.; Bechmann, N.; Jankord, R. Nutritional Ketosis Affects Metabolism and Behavior in Sprague-Dawley Rats in Both Control and Chronic Stress Environments. Front. Mol. Neurosci. 2017, 10, 129. [CrossRef]

7. Melø, T.M.; Nehlig, A.; Sonnewald, U. Neuronal-glial interactions in rats fed a ketogenic diet. Neurochem. Int. 2006, 48, 498-507. [CrossRef] [PubMed]

8. Hashim, S.A.; VanItallie, T.B. Ketone body therapy: From the ketogenic diet to the oral administration of ketone ester. J. Lipid Res. 2014, 55, 1818-1826. [CrossRef]

9. Kovács, Z.; D’Agostino, D.P.; Ari, C. Anxiolytic Effect of Exogenous Ketone Supplementation Is Abolished by Adenosine A1 Receptor Inhibition in Wistar Albino Glaxo/Rijswijk Rats. Front. Behav. Neurosci. 2018, 12, 29. [CrossRef] [PubMed]

10. D'Agostino, D.; Pilla, R.; Held, H.; Landon, C.; Puchowicz, M.; Brunengraber, H.; Ari, C.; Arnold, P.; Dean, J.B. Therapeutic ketosis with ketone ester delays central nervous system oxygen toxicity seizures in rats. Am. J. Physiol.-Regul. Integr. Comp. Physiol. 2013, 304, 829-836. [CrossRef]

11. Kovács, Z.; D’Agostino, D.P.; Dobolyi, A.; Ari, C. Adenosine A1 Receptor Antagonism Abolished the Anti-seizure Effects of Exogenous Ketone Supplementation in Wistar Albino Glaxo Rijswijk Rats. Front. Mol. Neurosci. 2017, 10, 235. [CrossRef]

12. Ari, C.; Poff, A.M.; Held, H.E.; Landon, C.S.; Goldhagen, C.R.; Mavromates, N.; D’Agostino, D.P. Metabolic therapy with Deanna Protocol supplementation delays disease progression and extends survival in amyotrophic lateral sclerosis (ALS) mouse model. PLoS ONE 2014, 9, e103526. [CrossRef] [PubMed]

13. Tefera, T.W.; Wong, Y.; Barkl-Luke, M.E.; Ngo, S.T.; Thomas, N.K.; McDonald, T.S.; Borges, K. Triheptanoin Protects Motor Neurons and Delays the Onset of Motor Symptoms in a Mouse Model of Amyotrophic Lateral Sclerosis. PLoS ONE 2016, 11, e0161816. [CrossRef]

14. Henderson, S.T.; Vogel, J.L.; Barr, L.J.; Garvin, F.; Jones, J.J.; Costantini, L.C. Study of the ketogenic agent AC-1202 in mild to moderate Alzheimer's disease: A randomized, double-blind, placebo-controlled, multicenter trial. Nutr. Metab. (Lond.) 2009, 6, 31. [CrossRef] [PubMed] 
15. Kashiwaya, Y.; Takeshima, T.; Mori, N.; Nakashima, K.; Clarke, K.; Veech, R.L. D-beta-hydroxybutyrate protects neurons in models of Alzheimer's and Parkinson's disease. Proc. Natl. Acad. Sci. USA 2000, 97, 5440-5444. [CrossRef]

16. Youm, Y.H.; Nguyen, K.Y.; Grant, R.W.; Goldberg, E.L.; Bodogai, M.; Kim, D.; D'Agostino, D.; Planavsky, N.; Lupfer, C.; Kanneganti, T.D.; et al. The ketone metabolite $\beta$-hydroxybutyrate blocks NLRP3 inflammasome-mediated inflammatory disease. Nat. Med. 2015, 21, 263-269. [CrossRef]

17. Kovács, Z.; Czurkó, A.; Kékesi, K.A.; Juhász, G. Intracerebroventricularly administered lipopolysaccharide enhances spike-wave discharges in freely moving WAG/Rij rats. Brain Res. Bull. 2011, 85, 410-416. [CrossRef]

18. Russo, E.; Andreozzi, F.; Iuliano, R.; Dattilo, V.; Procopio, T.; Fiume, G.; Mimmi, S.; Perrotti, N.; Citraro, R.; Sesti, G.; et al. Early molecular and behavioral response to lipopolysaccharide in the WAG/Rij rat model of absence epilepsy and depressive-like behavior, involves interplay between AMPK, AKT/mTOR pathways and neuroinflammatory cytokine release. Brain Behav. Immun. 2014, 42, 157-168. [CrossRef]

19. Kovács, Z.; D’Agostino, D.P.; Diamond, D.M.; Ari, C. Exogenous Ketone Supplementation Decreased the LipopolysaccharideInduced Increase in Absence Epileptic Activity in Wistar Albino Glaxo Rijswijk Rats. Front. Mol. Neurosci. 2019, 12, 45. [CrossRef]

20. Coenen, A.M.; Van Luijtelaar, E.L. Genetic animal models for absence epilepsy: A review of the WAG/Rij strain of rats. Behav. Genet. 2003, 33, 635-655. [CrossRef]

21. Meeren, H.K.; Pijn, J.P.; Van Luijtelaar, E.L.; Coenen, A.M.; Lopes da Silva, F.H. Cortical focus drives widespread corticothalamic networks during spontaneous absence seizures in rats. J. Neurosci. 2002, 22, 1480-1495. [CrossRef]

22. Vezzani, A.; Maroso, M.; Balosso, S.; Sanchez, M.A.; Bartfai, T. IL-1 receptor/Toll-like receptor signaling in infection, inflammation, stress and neurodegeneration couples hyperexcitability and seizures. Brain Behav. Immun. 2011, 25, 1281-1289. [CrossRef] [PubMed]

23. Kovács, Z.; Kékesi, K.A.; Szilágyi, N.; Abrahám, I.; Székács, D.; Király, N.; Papp, E.; Császár, I.; Szego, E.; Barabás, K.; et al. Facilitation of spike-wave discharge activity by lipopolysaccharides in Wistar Albino Glaxo/Rijswijk rats. Neuroscience 2006, 140, 731-742. [CrossRef]

24. Sayyah, M.; Javad-Pour, M.; Ghazi-Khansari, M. The bacterial endotoxin lipopolysaccharide enhances seizure susceptibility in mice: Involvement of proinflammatory factors: Nitric oxide and prostaglandins. Neuroscience 2003, 122, 1073-1080. [CrossRef] [PubMed]

25. Wang, Y.S.; White, T.D. The bacterial endotoxin lipopolysaccharide causes rapid inappropriate excitation in rat cortex. J. Neurochem. 1999, 72, 652-660. [CrossRef]

26. Almeida, C.G.; de Mendonça, A.; Cunha, R.A.; Ribeiro, J.A. Adenosine promotes neuronal recovery from reactive oxygen species induced lesion in rat hippocampal slices. Neurosci. Lett. 2003, 339, 127-130. [CrossRef]

27. van der Putten, C.; Zuiderwijk-Sick, E.A.; van Straalen, L.; de Geus, E.D.; Boven, L.A.; Kondova, I.; IJzerman, A.P.; Bajramovic, J.J. Differential expression of adenosine A3 receptors controls adenosine A2A receptor-mediated inhibition of TLR responses in microglia. J. Immunol. 2009, 182, 7603-7612. [CrossRef] [PubMed]

28. D'Alimonte, I.; D’Auro, M.; Citraro, R.; Biagioni, F.; Jiang, S.; Nargi, E.; Buccella, S.; Di Iorio, P.; Giuliani, P.; Ballerini, P.; et al. Altered distribution and function of A2A adenosine receptors in the brain of WAG/Rij rats with genetic absence epilepsy, before and after appearance of the disease. Eur. J. Neurosci. 2009, 30, 1023-1035. [CrossRef]

29. Kovács, Z.; Kékesi, K.A.; Juhász, G.; Dobolyi, A. The antiepileptic potential of nucleosides. Curr. Med. Chem. 2014, $21,788-821$. [CrossRef]

30. Sharma, A.K.; Rani, E.; Waheed, A.; Rajput, S.K. Pharmacoresistant epilepsy: A current update on non-conventional pharmacological and non-pharmacological interventions. J. Epilepsy Res. 2015, 5, 1-8. [CrossRef]

31. Brunner, B.; Rauch, E.; Ari, C.; D'Agostino, D.P.; Kovács, Z. Enhancement of Ketone Supplements-Evoked Effect on Absence Epileptic Activity by Co-Administration of Uridine in Wistar Albino Glaxo Rijswijk Rats. Nutrients 2021, 13, 234. [CrossRef]

32. Paxinos, G.; Watson, C. The Rat Brain Stereotaxic Coordinates; Academic Press: Orlando, FL, USA, 1998; ISBN 978-0125476171.

33. Sitnikova, E.; van Luijtelaar, G. Electroencephalographic precursors of spike-wave discharges in a genetic rat model of absence epilepsy: Power spectrum and coherence EEG analyses. Epilepsy Res. 2009, 84, 159-171. [CrossRef]

34. Kovács, Z.; Dobolyi, A.; Juhász, G.; Kékesi, K.A. Lipopolysaccharide induced increase in seizure activity in two animal models of absence epilepsy WAG/Rij and GAERS rats and Long Evans rats. Brain Res. Bull. 2014, 104, 7-18. [CrossRef]

35. Kovács, Z.; Slézia, A.; Bali, Z.K.; Kovács, P.; Dobolyi, A.; Szikra, T.; Hernádi, I.; Juhász, G. Uridine modulates neuronal activity and inhibits spike-wave discharges of absence epileptic Long Evans and Wistar Albino Glaxo/Rijswijk rats. Brain Res. Bull. 2013, 97, 16-23. [CrossRef] [PubMed]

36. Kovács, Z.; Czurkó, A.; Kékesi, K.A.; Juhász, G. The effect of intraperitoneally administered dimethyl sulfoxide on absence-like epileptic activity of freely moving WAG/Rij rats. J. Neurosci. Methods 2011, 197, 133-136. [CrossRef]

37. Levy, M.; Thaiss, C.A.; Elinav, E. Taming the inflammasome. Nat. Med. 2015, 21, 213-215. [CrossRef] [PubMed]

38. Patel, M.N.; Carroll, R.G.; Galván-Peña, S.; Mills, E.L.; Olden, R.; Triantafilou, M.; Wolf, A.I.; Bryant, C.E.; Triantafilou, K.; Masters, S.L. Inflammasome Priming in Sterile Inflammatory Disease. Trends Mol. Med. 2017, 23, 165-180. [CrossRef]

39. Bae, H.R.; Kim, D.H.; Park, M.H.; Lee, B.; Kim, M.J.; Lee, E.K.; Chung, K.W.; Kim, S.M.; Im, D.S.; Chung, H.Y. $\beta$-Hydroxybutyrate suppresses inflammasome formation by ameliorating endoplasmic reticulum stress via AMPK activation. Oncotarget 2016, 7, 66444-66454. [CrossRef] [PubMed] 
40. Fu, S.P.; Li, S.N.; Wang, J.F.; Li, Y.; Xie, S.S.; Xue, W.J.; Liu, H.M.; Huang, B.X.; Lv, Q.K.; Lei, L.C.; et al. BHBA suppresses LPS-induced inflammation in BV-2 cells by inhibiting NF-KB activation. Mediat. Inflamm. 2014, 2014, 983401. [CrossRef]

41. Fu, S.P.; Wang, J.F.; Xue, W.J.; Liu, H.M.; Liu, B.R.; Zeng, Y.L.; Li, S.N.; Huang, B.X.; Lv, Q.K.; Wang, W.; et al. Anti-inflammatory effects of BHBA in both in vivo and in vitro Parkinson's disease models are mediated by GPR109A-dependent mechanisms. J. Neuroinflammation 2015, 12, 9. [CrossRef]

42. Graff, E.C.; Fang, H.; Wanders, D.; Judd, R.L. Anti-inflammatory effects of the hydroxycarboxylic acid receptor 2. Metabolism 2016, 65, 102-113. [CrossRef] [PubMed]

43. Kovács, Z.; Dobolyi, A.; Kékesi, K.A.; Juhász, G. 5'-nucleotidases, nucleosides and their distribution in the brain: Pathological and therapeutic implications. Curr. Med. Chem. 2013, 20, 4217-4240. [CrossRef] [PubMed]

44. Simeone, T.A.; Simeone, K.A.; Stafstrom, C.E.; Rho, J.M. Do ketone bodies mediate the anti-seizure effects of the ketogenic diet? Neuropharmacology 2018, 133, 233-241. [CrossRef]

45. Andoh, T.; Ishiwa, D.; Kamiya, Y.; Echigo, N.; Goto, T.; Yamada, Y. A1 adenosine receptor-mediated modulation of neuronal ATP-sensitive K channels in rat substantia nigra. Brain Res. 2006, 1124, 55-61. [CrossRef] [PubMed]

46. Lakatos, R.K.; Dobolyi, Á.; Todorov, M.I.; Kékesi, K.A.; Juhász, G.; Aleksza, M.; Kovács, Z. Guanosine may increase absence epileptic activity by means of A2A adenosine receptors in Wistar Albino Glaxo Rijswijk rats. Brain Res. Bull. 2016, 124, 172-181. [CrossRef]

47. Kovács, Z.; Kékesi, K.A.; Dobolyi, Á.; Lakatos, R.; Juhász, G. Absence epileptic activity changing effects of non-adenosine nucleoside inosine, guanosine and uridine in Wistar Albino Glaxo Rijswijk rats. Neuroscience 2015, 300, 593-608. [CrossRef]

48. Germé, K.; Faure, J.B.; Koning, E.; Nehlig, A. Effect of caffeine and adenosine receptor ligands on the expression of spike-and-wave discharges in Genetic Absence Epilepsy Rats from Strasbourg (GAERS). Epilepsy Res. 2015, 110, 105-114. [CrossRef]

49. Nehlig, A.; Dufour, F.; Klinger, M.; Willing, L.B.; Simpson, I.A.; Vannucci, S.J. The ketogenic diet has no effect on the expression of spike-and-wave discharges and nutrient transporters in genetic absence epilepsy rats from Strasbourg. J. Neurochem. 2009, 109, 207-213. [CrossRef]

50. Pasquini, S.; Contri, C.; Borea, P.A.; Vincenzi, F.; Varani, K. Adenosine and Inflammation: Here, There and Everywhere. Int. J. Mol. Sci. 2021, 22, 7685. [CrossRef]

51. Martí Navia, A.; Dal Ben, D.; Lambertucci, C.; Spinaci, A.; Volpini, R.; Marques-Morgado, I.; Coelho, J.E.; Lopes, L.V.; Marucci, G.; Buccioni, M. Adenosine Receptors as Neuroinflammation Modulators: Role of $\mathrm{A}_{1}$ Agonists and $\mathrm{A}_{2 \mathrm{~A}}$ Antagonists. Cells 2020, 9 , 1739. [CrossRef]

52. Boison, D.; Chen, J.F.; Fredholm, B.B. Adenosine signaling and function in glial cells. Cell Death Differ. 2010, 17, 1071-1182. [CrossRef]

53. Sheth, S.; Brito, R.; Mukherjea, D.; Rybak, L.P.; Ramkumar, V. Adenosine receptors: Expression, function and regulation. Int. J. Mol. Sci. 2014, 15, 2024-2052. [CrossRef]

54. Synowitz, M.; Glass, R.; Färber, K.; Markovic, D.; Kronenberg, G.; Herrmann, K.; Schnermann, J.; Nolte, C.; van Rooijen, N.; Kiwit, J.; et al. A1 adenosine receptors in microglia control glioblastoma-host interaction. Cancer Res. 2006, 66, 8550-8557. [CrossRef] [PubMed]

55. Tsutsui, S.; Schnermann, J.; Noorbakhsh, F.; Henry, S.; Yong, V.W.; Winston, B.W.; Warren, K.; Power, C. A1 adenosine receptor upregulation and activation attenuates neuroinflammation and demyelination in a model of multiple sclerosis. J. Neurosci. 2004, 24, 1521-1529. [CrossRef]

56. Gessi, S.; Merighi, S.; Stefanelli, A.; Fazzi, D.; Varani, K.; Borea, P.A. A(1) and A(3) adenosine receptors inhibit LPS-induced hypoxia-inducible factor-1 accumulation in murine astrocytes. Pharmacol. Res. 2013, 76, 157-170. [CrossRef]

57. Colella, M.; Zinni, M.; Pansiot, J.; Cassanello, M.; Mairesse, J.; Ramenghi, L.; Baud, O. Modulation of Microglial Activation by Adenosine A2a Receptor in Animal Models of Perinatal Brain Injury. Front. Neurol. 2018, 9, 605. [CrossRef] [PubMed]

58. Gomes, C.; Ferreira, R.; George, J.; Sanches, R.; Rodrigues, D.I.; Gonçalves, N.; Cunha, R.A. Activation of microglial cells triggers a release of brain-derived neurotrophic factor (BDNF) inducing their proliferation in an adenosine A2A receptor-dependent manner: A2A receptor blockade prevents BDNF release and proliferation of microglia. J. Neuroinflammation 2013, 10, 16. [CrossRef]

59. Rebola, N.; Simões, A.P.; Canas, P.M.; Tomé, A.R.; Andrade, G.M.; Barry, C.E.; Agostinho, P.M.; Lynch, M.A.; Cunha, R.A. Adenosine A2A receptors control neuroinflammation and consequent hippocampal neuronal dysfunction. J. Neurochem. 2011, 117, 100-111. [CrossRef] [PubMed]

60. Brambilla, R.; Cottini, L.; Fumagalli, M.; Ceruti, S.; Abbracchio, M.P. Blockade of A2A adenosine receptors prevents basic fibroblast growth factor-induced reactive astrogliosis in rat striatal primary astrocytes. Glia 2003, 43, 190-194. [CrossRef]

61. Hindley, S.; Herman, M.A.; Rathbone, M.P. Stimulation of reactive astrogliosis in vivo by extracellular adenosine diphosphate or an adenosine A2 receptor agonist. J. Neurosci. Res. 1994, 38, 399-406. [CrossRef] [PubMed]

62. Fiebich, B.L.; Biber, K.; Lieb, K.; van Calker, D.; Berger, M.; Bauer, J.; Gebicke-Haerter, P.J. Cyclooxygenase-2 expression in rat microglia is induced by adenosine A2a-receptors. Glia 1996, 18, 152-160. [CrossRef]

63. Saura, J.; Angulo, E.; Ejarque, A.; Casadó, V.; Tusell, J.M.; Moratalla, R.; Chen, J.F.; Schwarzschild, M.A.; Lluis, C.; Franco, R.; et al. Adenosine A2A receptor stimulation potentiates nitric oxide release by activated microglia. J. Neurochem. 2005, 95, 919-929. [CrossRef] [PubMed]

64. Chakravarty, S.; Herkenham, M. Toll-like receptor 4 on nonhematopoietic cells sustains CNS inflammation during endotoxemia, independent of systemic cytokines. J. Neurosci. 2005, 25, 1788-1796. [CrossRef] 
65. Haskó, G.; Cronstein, B.N. Adenosine: An endogenous regulator of innate immunity. Trends Immunol. 2004, 25, 33-39. [CrossRef] 66. Brodie, C.; Blumberg, P.M.; Jacobson, K.A. Activation of the A2A adenosine receptor inhibits nitric oxide production in glial cells. FEBS Lett. 1998, 429, 139-142. [CrossRef] 